\title{
An explorative-descriptive qualitative-constructivist study of three African leaders' experiences and perceptions regarding the translation of shared African human values into leadership and business practice
}

\begin{tabular}{|c|c|}
\hline \multicolumn{2}{|c|}{$\begin{array}{l}\text { Authors: } \\
\text { Vusumuzi M. Vilakati }{ }^{1} \\
\text { Willem J. Schurink }^{1} \text { (D) }\end{array}$} \\
\hline \multicolumn{2}{|c|}{$\begin{array}{l}\text { Affiliations: } \\
\text { }{ }^{1} \text { Department of Industrial } \\
\text { Psychology and People } \\
\text { Management, Faculty of } \\
\text { Management, University of } \\
\text { Johannesburg, Johannesburg, } \\
\text { South Africa }\end{array}$} \\
\hline \multicolumn{2}{|c|}{$\begin{array}{l}\text { Corresponding author: } \\
\text { Vusumuzi Vilakati, } \\
\text { vilakati.v@gmail.com }\end{array}$} \\
\hline \multicolumn{2}{|c|}{$\begin{array}{l}\text { Dates: } \\
\text { Received: } 30 \text { June } 2020 \\
\text { Accepted: } 11 \text { Feb. } 2021 \\
\text { Published: } 29 \text { Apr. } 2021\end{array}$} \\
\hline \multicolumn{2}{|c|}{$\begin{array}{l}\text { How to cite this article: } \\
\text { Vilakati, V.M., \& Schurink, W.J. } \\
\text { (2021). An explorative- } \\
\text { descriptive qualitative- } \\
\text { constructivist study of three } \\
\text { African leaders' experiences } \\
\text { and perceptions regarding the } \\
\text { translation of shared African } \\
\text { human values into leadership } \\
\text { and business practice. SA } \\
\text { Journal of Human Resource } \\
\text { Management/SA Tydskrif vir } \\
\text { Menslikehulpbronbestuur, } \\
\text { 19(0), a1433. https://doi. } \\
\text { org/10.4102/sajhrm. } \\
\text { v19i0.1433 }\end{array}$} \\
\hline \multicolumn{2}{|c|}{$\begin{array}{l}\text { Copyright: } \\
\text { (C) 2021. The Authors } \\
\text { Licensee: AOSIS. This } \\
\text { is licensed under the } \\
\text { Creative Commons } \\
\text { Attribution License. }\end{array}$} \\
\hline \multicolumn{2}{|l|}{ Read online: } \\
\hline 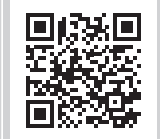 & $\begin{array}{l}\text { Scan this QR } \\
\text { code with your } \\
\text { smart phone or } \\
\text { mobile device } \\
\text { to read online. }\end{array}$ \\
\hline
\end{tabular}

Orientation: The study explores three African leaders' experiences, contextual influences and perspectives on how shared African human values can be incorporated into business leadership practice.

Research purpose: The study has twofold purposes: (1) to unravel and describe the experiences and perceptions of three business leaders in Africa, (2) to integrate the leaders' first-order conceptualisations with scholarly insights to construct a substantive framework for developing business leadership in Africa.

Motivation for the study: To explore contextual circumstances, which may enhance the formation of African shared human values in leaders and how these values may be translated into business leadership practice.

Research approach/design and method: This is an explorative-descriptive qualitativeconstructivist study of three African leaders' experiences and perceptions regarding the translation of shared African human values into leadership and business practice in the continent.

Main findings: The findings reveal that each of the three participants substantially embrace African shared human values in their daily actions and decision-making. Multiple themes covering the person, contextual and societal factors that influence the formation and use of these values are highlighted.

Practical/managerial implications: Business leaders, strategists and managers should explore strategies for employing shared African human values as a way of strengthening a valuesdriven business culture, employee performance, and stakeholder management.

Contributions/value-add: The findings suggest that incorporating shared African human values promises a more humane organisational culture and thereby improving businesses' financial and social performance in the African setting.

Keywords: African humanism; African shared values; business practice; case study; grounded theory; leadership practice; life-history; qualitative-constructivist approach.

\section{Introduction}

\author{
In his book, I Write What I Like, Biko (1987) writes:
}

$[W]$ e believe that in the long run, the special contribution to the world by Africa will be in the field of human relationships. The great powers of the world may have done wonders in giving the world an industrial and military look, but the great gift still has to come from Africa - giving the world a more human face. (p. 98)

The concept of humanity in Biko's metaphorical use of 'human face' is based on values embedded in African cultural philosophies, often described as African humanism (Mngxitama, Alexander, \& Gibson, 2008). The current discourse surrounding the humanisation of African political, economic and social life crosscuts a variety of social science fields including African leadership and management (Iwowo, 2015; Msila, 2017).

On Africa Day 2018, Ashom (2018) wrote a short article in the Independent Online Business Report, where she calls for the humanising of business and its leadership in Africa. Ashom (2018, para. 1) 
defines humanising as the ability to 'portray or endow with human characteristics or attributes; to make human'. Also, a number of African leadership and management scholars (Abegunrin \& Abidde, 2016; Gumede, 2017; Msila, 2017) have emphasised the need to rethink incorporating human values into African leadership practice. As Gumede (2017) rightly points out, often African leadership practices do not sufficiently honour African human values.

But why should African leadership actively try to incorporate human values into business leadership practice? In addition to the benefit of addressing 'what is humanly correct to do', such a task promises a more holistic and sustainable balance of relationships amongst businesses' internal and external stakeholders. It is also believed that in the context of the current economic situation, there is a need for a significant shift in business leadership practice to enable organisations to survive and thrive (Schwab \& Davis, 2018).

To better understand how to invoke the beneficial aspects of Africa's values into business leadership, one should first explore the nature of African business leadership, and the human values which its leaders interact with on a daily basis.

\section{African leadership}

What does 'African leadership' mean? Are certain leadership values, practices and contexts shared continent-wide? Is there a mostly singular approach to being an African leader? Or, do leadership values, practices and contexts vary extensively across settings?

The vastness of the African continent's historical, political, economic and cultural roots (Jackson, 2004) would seemingly lead to significant differences in leadership approaches. Africa's story encompasses endless events occurring across millennia and entails highly divergent political interactions and economic development occurring across a vast array of national, tribal, ethnic and religious boundaries (Kamoche, Chizema, Mellahi, \& Newenham-Kahindi, 2012). Besides, many commonalities exist across African leadership contexts and practice (Fourie, Van Der Merwe, \& Van Der Merwe, 2017).

Within African leadership and management research, there has been a persistent call to identify a continent-wide distinctive approach to leadership (Nkomo, 2006). Some scholars have begun the task of unifying and synthesising descriptions of leadership development and leadership practice across the continent (Amah, 2019; Fourie et al., 2017; Nkomo, 2006, 2015; Veldsman \& Johnson, 2016). Leaders and researchers searching for shared aims often use words and phrases such as 'African', Afro-centric, pan-African, 'African renaissance', 'African consciousness and leadership in, within, for or by Africans' to describe in part similarities they observe (Fourie et al., 2017; Iwowo, 2015). Many of these expressions share a common pan-African search for a deepened awareness of systemic leadership challenges facing Africa (Abegunrin \& Abidde, 2016).
Some have criticised the use of the term 'African leadership' as too monolithic (Jackson, 2004; Nkomo, 2006). In order to not essentialise the concept, some scholars (Jackson, 2004; Pillay, Subban, \& Govender, 2013) have opted to use 'leadership in Africa'. Cooper and Morrell (2014) pointed at the diverse epistemologies and ontological underpinnings of African research hampering the discovery of a monolithic view of what it means to be an African.

In the context of the preceding discussion, we regard 'African leadership' as intentionally Africa-centred and focused (Amah, 2019; Pillay et al., 2013). This points at a dynamic quest for understanding the complexity of interconnected historical trends, current trajectories and future needs in the African context (Jackson, 2004, 2018). 'African leadership' involves leaders 'who truly and sincerely believe that the destiny of Africa and its people lies in the ability of Africans to find solutions to Africa's problems' (Pillay et al., 2013, p. 105). Contextually driven African leaders focus on the continent's leadership and developmental challenges (Jackson, 2015; Ndlovu, 2015). Their leadership practice is grounded in shared indigenous cosmologies and knowledge systems on which African humanism is founded (Bell, 2002). As Amah (2019) points out, African leaders seek to translate these shared contextual values and practices into transformative, locally responsive and globally competent leadership responses.

\section{Shared African human values}

Linking Africa's human values with the future of business leadership in the continent requires an understanding of African humanism. Often referred to as the cradle of humankind', Africa has a rich history of community life and leadership wisdom that predates the colonial era (Maslin, 2017). Historians argue that a substantial amount of Africa's leadership wisdom dates back to early empires such as West Sudan (500 BCE), Ghana (790 CE) and Mali (1230 CE) (Gutto, 2013). To this day, this wisdom exhibits itself in a very simple form: most indigenous Africans have inherited 'praise names' in addition to their surnames (Mbiti, 2015).

These praise names often trace the individual's clan history and honour, that is, the person's connectedness to family, belonging to community and the environment and their strengths and anticipated contributions to society (Rukuni, 2007).

African humanism distinguishes itself from classic western humanism in several ways. According to Bell (2002):

$[T]$ he western, classical notion of humanism stresses a particular concept of education and civilization; it is premised on ancient Greek ideals such as balance of the arts and sciences, cultivation of individual virtues, and the exercise of rational self-control. (p. 39)

At its heart is the valuing of cultivated skills, individual freedom and civil rights. A western humanist is typically a champion of secular, ecclesiastical and/or moral freedoms, 
whose success is measured by material and intellectual achievements. African humanism, on the other hand, holds the promise of creating a world around human dignity, excluding the contradictions of western humanism (Wilder, 2005). It is based on collective moral values that are considered worthwhile for human well-being and building a cohesive society (Mbiti, 2015). Also, it entails a practice upholding the dignity of the human face of life over time in harmony with both living, non-living and cosmic supernatural realties (Viriri \& Mungwini, 2010). Bell (2002, p. 39) believes that African humanism entails a way of thinking and living which emphasises the constructive agency of human beings. Finally, African humanism is based on embracing a person's position within the broader social, cultural, economic and cosmic order of things (Bell, 2002).

African humanism as a research discipline emerged in the middle of the 20th century through the works of the Senegal intellectuals, Cheikh Diop and Léopold Sédar Senghor (Jacques, 2011). Over the last half century, African humanism with strong liberation themes found its expression in philosophy, literature, theology, political theory and political economy (Coetzee \& Roux, 2004). Notable present-day African humanism thinkers include Kwame Nkrumah, Wole Sonyika, Franz Fanon, Steve Biko, Chinua Achebe, Desmond Tutu and Ngũgĩ wa Thiong'o (Encyclopedia.com, 2019).

A dissected description of African humanism's key values includes the following: communal interdependence and belonging, harmony and cooperation, human solidarity, respect and custodianship of life and cultivating a caring community (Pillay et al., 2013). Attitudes associated with these values incorporate humility, thoughtfulness, connectedness, consideration and focus on traditional wisdom, social sensitivity, reciprocity and tolerance and regard for humane virtues (Irele \& Jeyifo, 2010). It is important to take cognisance of the fact that English language is generally inadequate to fully describe African humanism (Msila, 2017).

Values and attitudes central to African humanism are embodied in several slightly varied philosophical concepts from across Africa. They include Ubuntu, Botho, Bantu, Uhnu, Avandu and bunye (Southern Africa); Ujaama, Watu and umoja (Eastern Africa); Ngumtu, Kubuntu and Edubuntu (Central Africa); and Amani, Ogbara, ise and Ika (West Africa) (Rukuni, 2007). These form the unifying philosophical, anthropological and sociocultural premise for an African to identify facilitation and relational ways of thinking and being (Abegunrin \& Abidde, 2016).

Widely discussed are Ubuntu (Zulu), Botho (Sotho) or Unhu (Shona), which are derived from the Southern African 'maxim Umuntu ngumuntu ngabantu (Motho ke motho ka batho)' (loosely translated as 'I am a person through other people' (Coetzee \& Roux, 2004, p. 272). Ubuntu-Botho-Uhnu provides an integrative framework for understanding African personhood, connectedness and flourishing in a community.
According to Tutu (1999, pp. 34-35), Ubuntu-Botho-Uhnu means 'I am human because I belong, I participate, I share'. Drawing on Wilber's integral conception of reality, Forster (2010, p. 10) observes that Ubuntu philosophy integrates the objective, subjective and intersubjective aspects of identity facilitation. Human beings discover their individual, mutual and shared dignity and identity through a dynamic engagement with others, their environment and the supernatural realm of life.

Ubuntu-Botho-Uhnu comprises an extended perspective of the African communal conception of life; from an African cosmology perspective, life is regarded as an ongoing connectedness with 'the living, the living dead' (ancestors) and the future generations (Irele \& Jeyifo, 2010, p. 312). Emphasis is placed on the continuity of the past, present and future as one single point in the present (Matupire, 2016). Whilst participating in generating and distributing material and non-material resources, people are custodians of the past, present and future (Matupire, 2016).

African consciousness involves the ethical principles of putting the common interests and advancement of community above all things. As Lutz (2009) emphasises, it involves, firstly, encouraging affinity and equality in all social relations, and, secondly, developing the individual. In its purest form, African humanism should be viewed as a dynamic way of dialogue for facilitating community building and social cohesion (Ntibagirirwa, 2009). As important leadership engagement and consensus building practice, African humanism should never be allowed to regress to a static or archaic management burden (Lutz, 2009). In contrast, holistic transformation responsive to continual developmental challenges should be strived for.

At the foundation of African human consciousness lies the primacy of strong and effective individuals, who co-creatively, in turn, form families, communities and organisations. Families, communities and organisations can only be as strong as their participating individuals; likewise the individuals' strength is enhanced by the force of their families, communities and organisations (Rukuni, 2009). It is important to note that the current focus on maintaining the status quo of national and larger business institutions leaves a substratum of weak individuals, families and communities (Rukuni, 2007, 2009).

\section{Towards creating African business leadership practice enhanced by shared African human values}

According to Khoza (2007):

African leadership is dominated by values ... internalised forces of predisposition which predispose people to behave and act in a certain way. Values are deeper than feelings, deeper than opinions and attitudes, albeit in the same vein. (p. 24)

In the African setting, these values create a particular world view, an Afrocentric way of existence and consciousness. 
This consciousness, Khoza (2007, p. 24) continues, is about anchoring people 'in their own continent; its history, traditions, cultures, mythology, creative motif, ethos and value systems exemplifying the African collective will'.

The West has typically been the reference point for humanity, modernisation and leadership development (Ahluwalia, 2012). In order to relate its people with their resources and the wider world in a way that enhances the natural creativity of individuals, communities and their leaders (Gumede, 2017; Iwowo, 2015), Africa must recognise and implement its own world view.

Over the last few decades, African countries have experienced substantial expansion and growth in their economies and business turnover (Walsh, 2015). This has created both opportunities and challenges for business leadership. Given the continent's growth and change trajectories, the future world of African business is most certainly going to look different. Veldsman and Johnson (2016) characterise this emerging business context as a world of increasing volatility, uncertainty, complexity and ambiguity.

In this environment, well-targeted business leadership responses are critical to help move Africa's social and economic advancement beyond the continent's historical legacies and current realities (Iwowo, 2015). Those who lead business in Africa are challenged to maintain responsible and high-performing organisations that will create wealth and contribute to the prospering of its societies (Vilakati, Schurink, \& Van Wyk, 2018).

The success of Africa's advancement is likely to be enhanced by (1) its ability to discover contextually attuned, effective and innovative leadership (Adesida, Karuri-Sebina, \& Resende-Santos, 2016), which is enhanced by (2) its ability to reclaim African leadership wisdom and shared human values (Gumede, 2017; Msila, 2017).

According to Gumede (2017), effective implementation of the continent's wisdom and values in business leadership requires (1) thought leadership - the capacity to intellectually appropriate and prioritise Africa in the current global space; (2) thought liberation - the cultivation of independent thinking devoid of colonial baggage and (3) critical consciousness - deep levels of awareness that are not easily swayed by dominant thinking.

\section{The present study}

Currently lacking in African business and management thought is a perspective of how the strong belief in the common good inherent in shared African human values is translated and may be better translated into business practices that benefit African society. The study begins to address this challenge in several ways: (1) it unravels and describes the experiences and perceptions of three African business leaders; (2) it generates insights surrounding the context supporting the use of shared values in African business; (3) it generates insights on which shared African human values may guide business leaders' workplace actions and (4) it generates insights on which personal circumstances shape managers to implement these values.

\section{Method}

Utilising a qualitative-constructivist approach (Schwandt, 2014), life history (Plummer, 2001) and grounded theory (Charmaz, 2016) are employed as data gathering and analysis strategies. As Denzin and Lincoln (2017) point out, qualitative research approaches are used to (1) unravel social phenomena within their natural context, (2) capture dynamic social and processual components of research including the researcher-participant relationship and (3) generate data with rich descriptions to interpret social phenomena in context. Using these positions and approaches, we generated and describe the subjective experiences and perspectives of three senior business executives from three African countries.

Underpinned by a subjective ontology and epistemology, the constructivist research paradigm asserts the existence of multiple truths and realities, and interpretations of social phenomena (Charmaz, 2016). These realities and ways of seeing and understanding the social world are embedded within a particular social and cultural context, and within a specific time frame (Denzin \& Lincoln, 2017).

In line with the preceding paradigm, we employed a hybrid strategy that combines a multiple case study, life history (Goodson, 2016; Plummer, 2001) and grounded theory (Charmaz, 2006) in unravelling and describing rich experiences and perceptions of the three business leaders' personal, social, cultural, economic and political contexts. We used grounded theory which allows for an iterative reflection in context and which give voice to individual experiences and perspectives (Goodson, 2016) in order to analyse and interpret the leaders' worlds.

\section{Research setting}

We decided on African business leadership as research setting. By Africa, we refer to the geographical boundaries of the continent. We looked for senior executive business leaders with wide-ranging experience across a variety of business sectors in Africa and beyond. We did not focus on any particular area of business specialisation, but instead searched for leaders who had crossed organisational and disciplinary boundaries.

We sought leaders who had multi-national exposure. In a nutshell, we sought leaders with a good understanding of (1) Africa's complex historical and political realities, (2) its past, current and future economic trajectories, (3) its social/cultural context and (4) the beneficial values found in African humanism and their relevance to business leadership practice. 


\section{Entree and establishing researcher roles}

We invited the three research participants to participate in the study in their individual capacity and not as representatives of any particular organisation. Thus, no permission was required from their organisations. In building trust with the participants and ensuring respectful and ethical research, the first author employed various researcher roles.

\section{Sampling}

We selected research participants through reseacher's contacts and by employing purposive sampling (Yin, 2013). As Plummer (2001) suggests, storytellers need to be individuals who are information-rich, accessible and prepared to participate in research, and who could provide in-depth information on the research subject.

Not looking for a marginal person who represented a specialised or extreme case, or a great person or public figure, we sought ordinary leaders who were knowledgeable about African business leadership. Each participant selected has more than 20 years of business leadership experience. Their experience spans across several African and international organisations and a variety of sectors, including consulting in strategic human resource (HR) management, remuneration, organisational development, business science and development, banking and risk management, international finance and investments, and strategic development and marketing.

The business leaders' profiles can be summarised as follows:

- Leader 1 is African black male of Ghanaian origin in his mid-40s. He is a male senior executive in the financial sector. He studied at international schools and universities and has lived and worked in the United Kingdom (UK), Nigeria, South Africa and the Ivory Coast. His work experience covers key strategic and pioneering roles in at least three pan-African banking conglomerates, one with operations in 36 African countries. Currently residing in Johannesburg, he was instrumental in setting up a branch of the African bank in prominent business districts in South Africa. He displays strong business management skills and excellent networking abilities. Being passionate about African leadership and emerging markets, he is always looking for ways of improving economic value through collaboration and networking.

- Leader 2 is a black Zimbabwe-born female senior marketing and strategy executive. In her 40s, she completed postgraduate $\mathrm{PhD}$ academic studies in marketing. Her professional experience includes intercontinental leadership, teaching, consulting and strategic management. Being passionate about Africa's people, business and development, she has played key consultancy roles in international investment and Africa's economic development. Growing up with her parents in international service, she studied, lived and worked in Ethiopia, Europe, UK and South Africa. She is a key player in Africa's economic and policy development, and currently heads one of Africa's leadership development agencies. Formerly, she was employed as a senior strategist for a leading development finance institution in Africa.

- Leader 3 is a white South African male in his early 50s and a business executive and entrepreneur who is currently the chief executive officer (CEO) for a human capital and organisation development consulting company that consults in more than eight African countries. Starting of as an educator, he became a banker and worked as an HR consultant for two international banks, responsible for South Africa, East Africa, West Africa and the Middle East. Having consulted in more than 20 different countries on issues dealing with aspects of human capital and change management, his experience includes senior roles in freight, fleet and financial services industries. Leader 3 is a leading human relations strategist who has developed an array of HR-enabling products.

\section{Data collection methods}

The process of preparation, gathering and documenting the life stories took place over a period of 1 year. The data gathering process consisted of eight face-to-face in-depth unstructured and semi-structured interviews, each lasting for $50 \mathrm{~min}$ - $70 \mathrm{~min}$. Employing Plummer's (2001) life course events, the researcher first asked about the participants' earliest recollections in order to guide them in sharing their personal backgrounds, life chapters, key scenes, values and vocational experiences. As Plummer (2001) points out, linking life course events with a historical time as well as with context enriches the process of generating the life history. Following Plummer (2001), the first author interview process followed the leaders' biographical timeline, beginning with general background and family details, moving to education, career choices and professional experiences and ultimately focusing on their experiences and insights on shared African values in leadership and business leadership's role in advancing the continent.

Following Plummer (2001), the first author considered (1) substantive questions, that is, concrete, empirical questions focusing on what one wants to know; (2) social science questions, the type of knowledge one strives for; (3) technical questions concerning processual details involved in executing the research, the 'how' of social research; (4) ethical and political questions, the so-called extra-technical and extrascientific research issues relating to justifying the study, its ethical implications and ensuring that no one is marginalised during the research; and (5) personal questions, or questions related to the dual impact of the research on the researcher's life and the research participants.

Also, reflecting his constructivist stance, the first author aligned the phrasing of the interview questions. He put the participants' stories in the foreground whilst keeping his personal interest as far as possible in the background. Therefore, whenever he posed questions, he remained flexible, giving the storytellers the opportunity to steer the conversation, whilst at the same time maintaining the 
research focus. We believe that this modus operandi facilitated a co-constructivist relational space between the storytellers and the researcher.

Creating a life history typically involves triangulating data from interviews, participant observation, document review, artefacts and researcher field notes and memos (De Chesnay, 2014). Therefore, interviews were supplemented with online conversations, document analysis, as well as participant observation, that is, Vilakati and the three business leaders interacted in the latter's setting (Taylor \& Bogdan, 1984). Also, he observed the business leaders' office structure and the symbols they kept. The various images they had on their walls, along with observations of their office environment, provided him with valuable insights into personal values and the way each functioned within his or her particular business facility. In short, we believe that participant observation gave Vilakati the opportunity to observe the experience and behaviour of the research participants in their respective situations and settings, first hand (Waddington, 2004).

Part of the life history data was obtained from sources other than interviews and observations. Several documents and media reports relating to the participants were available. Leader 2, in particular, has written several academic and business articles, and has a number of recorded video segments available online. The researcher read the scripts and made notes of these documents.

\section{Capturing and storing the data}

Conducting the interviews, the researcher watched, actively listened and recorded supplemental data. More specifically, as Menter, Elliot, Hulme, Lewin and Lowden (2011) point out, he created field notes and memos containing reflective insights. After each interview, he made an array of field notes which reflected on the data, the process and his observations.

The first author audio recorded the interviews and transcribed the recordings - not verbatim copies of the original reality; instead, as Brinkmann and Kvale (2018) correctly point out, they are researcher-mediated interpretations and constructions for given research purposes.

Vilakati also kept a research journal as a reflective tool to aid the process of triangulating data sets (Ward, 2014). Journaling is a creative process that helps one to interrogate your assumptions and intuitions, reflect on your observations and clarify your ideas (Butler-Kisber, 2010).The journal included details of procedural plans, key learnings, research notes, insights and adjustments in terms of the research timeline, and reflections on the entire process. Several of the entries contained ideas he thought had theoretical underpinnings and required follow-up and, in some cases, included his personal reflections of participants' views and perceptions. These entries also assisted him in developing theoretical ideas, clarifying his role as a researcher as well as in making processual choices and changes along the course of the study.
Finally, all the data were stored electronically in a passwordprotected online Dropbox server. Hard copies of research files and documents were filed in a secure office at his home.

\section{Data analysis and interpretation}

The process of grounded theory analysis followed three iterative and interrelated steps, namely, initial (open), focused and theoretical coding (Charmaz, 2016). Initial coding involved carefully reading the transcripts sentenceby-sentence to identify words and phrases that could be clustered into concepts, categories and themes (Charmaz, 2016). In total, Vilakati identified about 300 codes and distributed them across eight themes, namely, family background and context, education and career context, personal values and attitudes, economic and business context, political and sociocultural context, leadership development and response, African values and African advancement.

The focused coding phase involved using constant comparison to crystallise and integrate the most significant and frequently coded themes (Charmaz, 2016). Lastly, Vilakati performed theoretical coding to refine and integrate the first-order constructs generated from the life stories, with scholarly insights from African leadership and management literature. Theoretical coding enabled him to organise, synthesise and integrate the key categories into a storyline around two key themes - African wisdom and values and themes supportive of enhancing values in business leaders (Charmaz, 2016).

\section{Reporting style}

The thesis from which this article is compiled reflects various qualitative writing styles. We strove towards a stimulating reading experience that would engage the reader, yet still meet academic rigour. Simple, clear and accessible writing was ensured and formal academic writing (the so-called scientific tale) contextualises the study and outlines the research approach, research strategies and research methodology. Whilst most of the formal arguments are presented in the third person, the first person was generally used for describing the research process and its various decision-taking steps. Also, tables and figures served to bring to life and illuminate portions of the data and research process descriptions. Excerpts from interviews were provided and pictures were offered. Finally, a socalled research story, backstage (Schurink, 2011) or teflexive ethnography (Ellis, 2004) was compilled. Ellis (2004) writes:

... $[D]$ ocument(s) ways a researcher changes as a result of doing fieldwork. Existing on a continuum ranging from starting research from the ethnographer's biography, to the ethnographer studying her or his life alongside cultural members' lives, to ethnographic memoirs ... or 'confessional tales' (Van Maanen, 1988) in terms of which the ethnographer's backstage research endeavours become the focus of the investigation. (p. 50) 
Vilakati constructed a backstage narrative to share special real-life moments of the study as well as to serve as an internal audit for assisting with assessing the research.

\section{Strategies to ensure data quality and reporting}

The authors ensured quality data by providing rich and detailed descriptions of the research participants' subjective experiences (Schurink, 2009). More particularly, he incorporated Lincoln and Guba's (1985) widely accepted and recognised criteria for demonstrating trustworthiness in qualitative research studies, namely, credibility, transferability, dependability and confirmability.

In order to ensure credibility, data gathering and analysis methods were triangulated (Yin, 2013). The respective phases of the entire research process were carefully documented to ensure that the findings are transferable to other settings. Vilakati ensured dependability by employing member checking, that is, obtaining the participants' evaluation of the findings. Finally, data confirmability was safeguarded by clearly articulating the interactive processes during the study and compiling a research story as an audit trail (Schurink, 2009).

\section{Ethical considerations}

Ethical clearances and approval to conduct the study was obtained from Ethical Clearance Committee of the College of Business and Economics of the University of Johannesburg (reference number IPPM 2016-018 - PHD). The interviews were conducted in a respectful and ethical manner, ensuring interview etiquette and participant confidentiality. Each participant was properly brief and they all agreed to sign a letter of informed consent. This letter dialogue the research process, confidentiality and voluntary nature of participation that they could withdraw from the research at any point in time.

\section{Findings}

Three main themes emerged when we integrated the three business leaders' stories with insights we obtained from scholarship: (1) the personal values and attitudes adopted by leaders in the workplace, (2) the societal context surrounding the use of these values and (3) circumstances that influence leaders' adoption of African values.

The findings are summarized in Table 1. In the ensuing discussion, we expand on those mostly emphasised by the three leaders.

TABLE 1: Themes and subthemes derived from the coding process relating to the use of shared African human values in the workplace by the three African leaders.

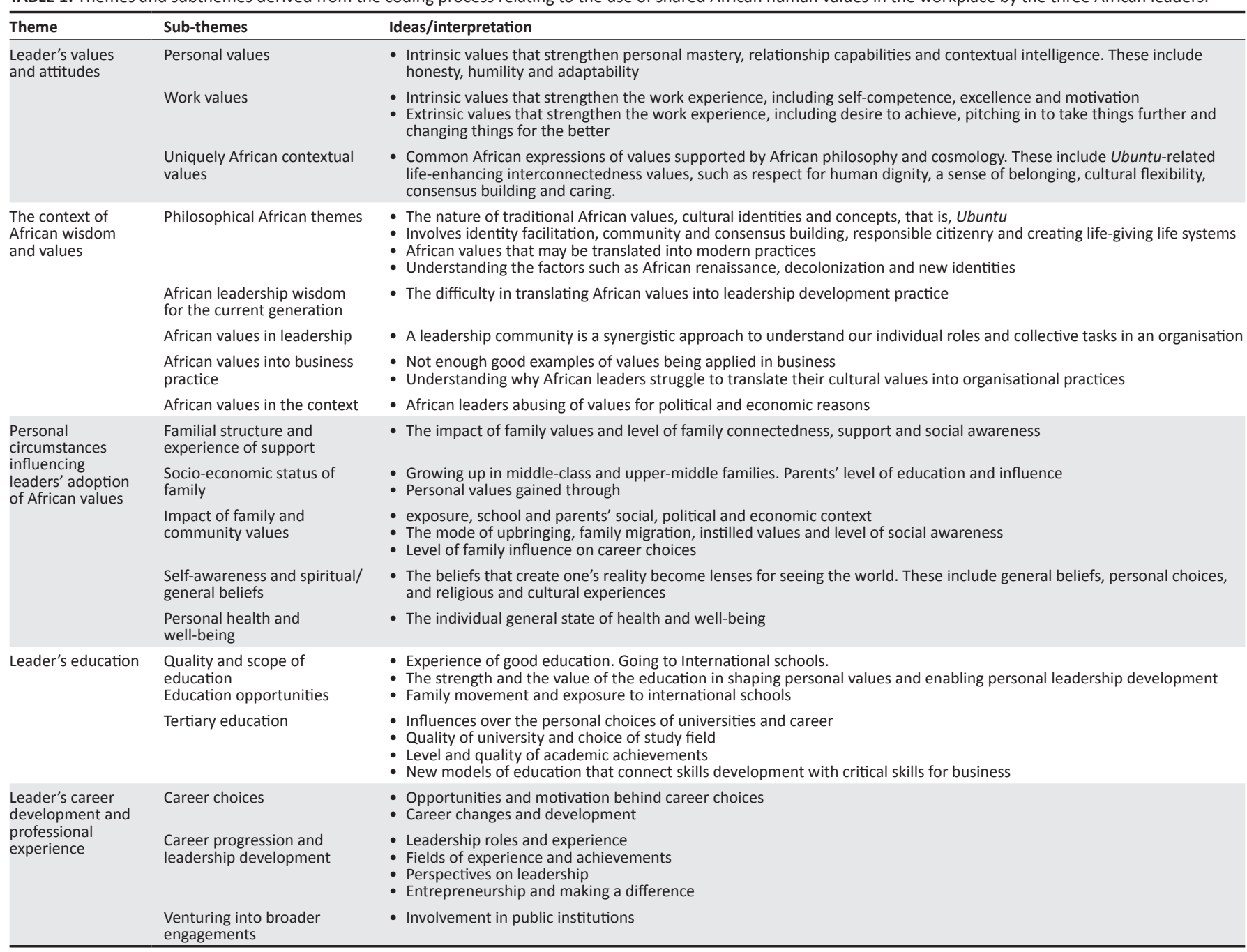




\section{Discussion}

Figure 1 presents a summary of the most highlighted themes related to the shared African values, their context and formational influences as described in the three leaders' life histories. Let us now take a closer look at these themes.

\section{Theme 1: Distinguishing African wisdom-based work values from those of personal work}

In reviewing the African business leaders' personal values in terms of their work values, several thrusts emerged that are shared by global leaders. These included a common interest in achieving intrinsic qualities of self-competence, excellence, sustainable motivation and extrinsic qualities, including the desire to achieve respect for all people, making a difference and pitching in to take matters further and to change them for the better. According to Leader 3, 'in general, these work values are true for a leader anywhere in the world ... in the African setting they are highlighted by the strong focus on human relationships'.

As we reflected on the leaders' stories, it was evident that there was an additional emphasis on personal and work values embedded in African humanism, as as eloquently captured by Leader 1 :

'I learned the importance of caring about the needs of my family, extended family and being a good citizen from my family, especially the values that were always hidden in my grandmother's daily stories.'

These values are resonant with those found in African leadership research, such as 'caring, community, harmony and hospitality, respect and responsiveness' and custodianship of life (Asamoah \& Yeboah-Assiamah, 2019).

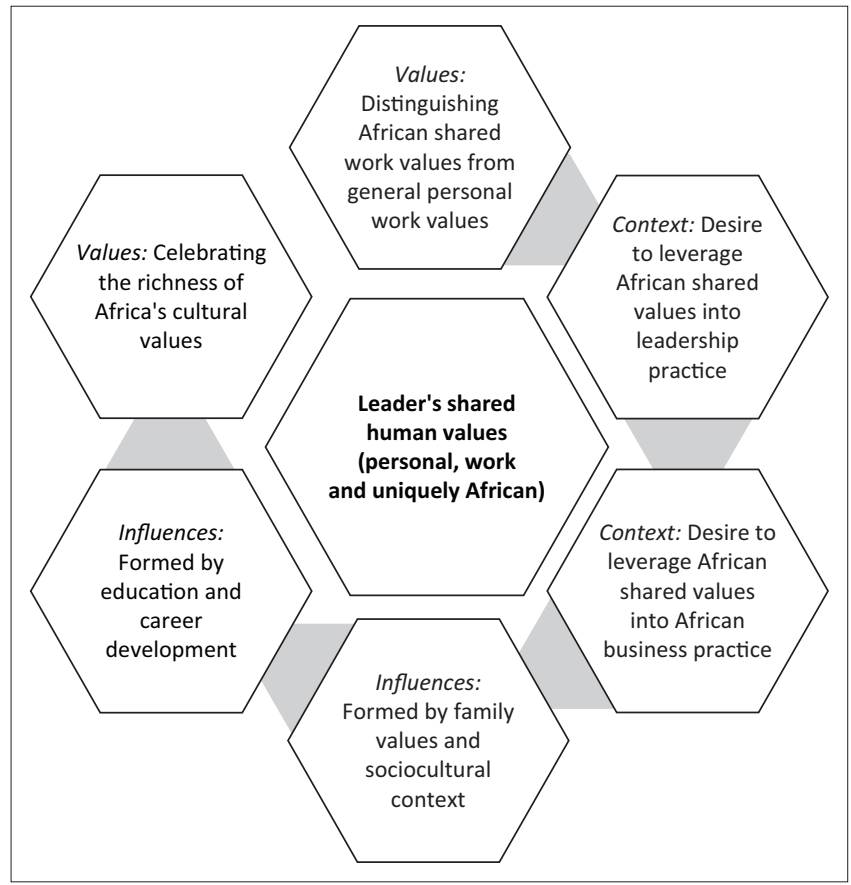

FIGURE 1: Leaders' shared African values according to context and formation influences.
Associated attitudes include humility, thoughtfulness, connectedness, understanding, a focus on traditional wisdom, generosity, social sensitivity and reciprocity, sharing, tolerance and regard for human virtues (Kazeroony, 2016). These values are acknowledged by current African management studies (Amah, 2019; Asamoah \& YeboahAssiamah, 2019; Gumede, 2017; Iwowo, 2015; Nkomo, 2015).

\section{Theme 2: Celebrating the richness of African cultural values}

Whilst all three participants lived and worked outside Africa, they believe that the continent is their home, in large part because of its cultural richness. In Leader 3's words:

'[T] his is my home; I was born here, I live here, I have started my business here ... while there may be so many challenges ... and psychological costs of being a white male in this country (South Africa), Africa is a great continent ... I want to make a difference here in Africa, making it a better place ... I know some of my white friends have opted to immigrate ... or register their business outside the continent ... but I see the potential in African business.'

The leaders strongly see themselves as Africans and rooted in the continent's history and current realties and cultural expressions. They all highlighted the beauty of the continent's rich and diverse cultures, languages and the centrality of respect and humane behaviour in most cultures of the continent. Leader 1 referred to the concepts of Ubuntu in Southern Africa, Ujamaa in East Africa and Weku in his native Ghana culture. At the core of these concepts lie the African cultures of harmonious, caring and supportive human relationships and respect for human life (Kazeroony, 2016).

Whilst the participants were celebrating the positive aspects of African cultures, they were also fully aware of their negative aspects, such as paternalistic tendencies, ageism or grey hair syndrome (Leader 1), racial tensions (especially in South Africa) (Leader 3), patriarchy and entitlement by those who were involved in the struggle for independence (Leader 2). These aspects have largely been the source of political instability, economic inequality, lack of regional cooperation and corruption in business and governments (Asamoah \& Yeboah-Assiamah, 2019).

\section{Theme 3: Leveraging African contextual wisdom and values}

All three leaders lamented the poor application of and the need to leverage African human values in the workplace:

'[A]frican values can be used to support leadership development ...; we can create institutions with an African spirit ... these values can also inspire a united Africa.' (Leader 1)

' $[W]$ hen we started our company, we wanted it to be a panAfrican organisation ... As Africans, we are dynamic people ... we are respectful ... we are good relationship builders ...; we are generally inclusive in our approach ... when there is a deal at hand, we ask who else should be involved ....' (Leader 3)

Leader 2 referred to young professionals who have been trained in reputed institutions in the United States of America 
and Europe and who came back to invest in Africa and leverage cultural elements. A specific example given was about a young person who developed a reputable clothing line using some African cultural fabrics (Leader 1).

The above insights by and large represent the common ethos within African values. According to Biko (2019), African leaders and organisations have the task of implementing and leveraging several cultural (pan-African) particularities, such as collective leadership, enhancing the centrality of personhood, embracing the strong belief in servant leadership, as well as the holistic conception of reality. When leaders are authentically grounded in African values at the personal level, they are inspired to act as responsible corporate citizens with an inclination towards the common good (Malunga, 2009).

\section{Theme 4: Translating African values into organisational practice}

The importance of translating human values into all levels of organisational practice and stakeholder engagement was highlighted by all three leaders. In Leader 3 words:

'... [I] wish there were a way these values could be employed in leadership ... especially in government ... I really would like to see how business leaders and governments translate the values such as Ubuntu into authentic business practices ... because if they were able to, more businesses would emulate them and contribute to the advancement of societies.' (Leader 3)

Leader 1 also emphasised the need to create institutions with an African spirit. This is in agreement with Malunga (2009) who underlines the need for African organisations to exhibit the continent's positive values in their leadership development and organisational strategies. The leaders agreed that the wisdom contained in African values is important. The major challenge these posed is the struggle in translating them into organisational practice.

\section{Theme 5: Being grounded in family and leaders' sociocultural background}

There is a strong belief in most African cultures that values are shaped by family background and community (Rukuni, 2007). Also, a person's values are influenced by socioeconomic status, self-awareness and spiritual/general beliefs and their general health and well-being (Bass \& Bass, 2009).

The three leaders' accounts highlight the importance of being grounded in family as well as their sociocultural context. Each leader spoke about distinct values related to work, gender roles, social class, family, religion, education and a variety of other life and professional dimensions having shaped their experience and values:

'... $[A]$ s grandmothers are known, she would delight in telling us stories. These stories were often a mixture of humorous and didactic folk tales imbued with Ghana's farming culture; tales celebrating the virtues of working hard to gain the harvest, counter-posed by cautionary tales of lazy farmers shirking hard work and stealing other farmers' crops in the middle of the night; tales of obedient children who respected their parents and tales of children who learned through hardship how to be good.'

'... [T] he one thing that held our family together was our Christian Methodist faith and the support system provided by our families back in Ghana.' (Leader 1)

Other important incidents and circumstances shaping the leaders included their exposure to different cultures through experience in their upbringing of multiple contexts and international experiences. Leader 1, for example, outlined: '... having been exposed to various cultures has had an influence on me: even now, if I cook dinner, I'll think, let me cook Nigerian today or Thai or Indian or Chinese'. During her childhood, Leader 2's parents worked for Zimbabwe's foreign ministry and were posted in a few embassies in East Africa and Europe. As a result, she studied in international schools, and ultimately obtained a $\mathrm{PhD}$ in international marketing. Her current position has a strong international perspective and emphasis, embodied within the value sets she formed during her childhood.

Also, worth noting is the influence of parents on the leaders' level of education, and to a lesser extent their career choice. Each pointed out that their families believed in the value of education in shaping one's future. The families ensured that the participants received education from very reputed schools and universities both in Africa and the UK.

As suggested in the leader's insights, Bell (2002) observe that the level of exposure and cultural socialisation processes facilitate the broadening of individuals' world view. For example, both Leader 1's and Leader 2's parents were involved in leading reputed business and government institutions. As a consequence, these leaders have an acute awareness of the needs of both public and business leadership affairs. Such exposure allows them to see better the value of using shared African values to address the corruption found in some African societies.

\section{Theme 6: The importance of formal education and career experience}

A review of the leaders' educational experiences and career context reveals the impact of these experiences in shaping the leader's personal and work values. All three leaders had formal academic experience in reputed public and international schools and universities. As Leader 2 puts it:

'... [I] studied in international schools and got exposed to a number of educational and cultural experiences from a young age ... I then went to a university in the UK ... actually I completed my Masters and PhD in marketing and international relations in the UK ... I guess that makes me an international citizen.'

Recounting his university experience, Leader 1 observes, it helped to have parents who were already in business ... their guidance landed me at a university in the UK doing a basic 
degree and master's in international finance. As suggested by Ndlovu (2015), African leaders should exhibit their sense of rootedness to context and community in team development processes and organisational goal-setting processes. Also, all three leaders have worked across a number of sectors in Africa and in more than one continent.

By employing the richness of local and global knowledge, leaders are able to innovatively navigate the complex relationships between internal and external business stakeholders within Africa (Ayuso, Rodríguez, García-Castro, \& Ariño, 2014). In Leader 2's words, 'it helps to have a global perspective in order to understand the dynamics of the African continent ... and leverage her priorities across the key global value chains'.

\section{Translating shared African human values into leadership and business practice}

The themes we identified support the idea of nurturing a value-based leadership that is entrenched in the African values of humanness, solidarity and interdependence (Kazeroony, 2016). To effectively translate them into leadership and business practice, it appears that one must embrace an understanding of the continent's cultural heritage, as well as its current challenges and future priorities (Edozie, 2017). Individual leaders or the businesses they serve can adapt these values.

According to Jackson (2004, p. 3), developing African leadership within its current multi-cultural context should be a process of 'reconciling, integrating and synergising' of essential (local and global) elements of leadership and management. He (Jackson, 2004, p. 3) adds that developing African leadership within the current multi-cultural context should be a process of 'reconciling, integrating and synergising' of the essential (local and global) elements of leadership and management. The context, values and experiences of African business leaders should be integrated into what Hassanzadeh, Silong, Asmuni and Wahiza (2015, p. 137) have identified as the seven competencies points of effective global leaders, namely, 'culture awareness and sensitivity, global mindset or perspectives, learning from experiences, developing and maintaining relationships, communication, traits or attitudes, and knowledge and skills'.

Besides these skills, leadership in present-day Africans requires stronger abilities to effectively engage the increased energy in interaction between business and society (Edozie, 2017). Adequately employed, the African value system provides a perspective in which all people should be agents of the common good in a manner that facilitates social and economic solidarity and cooperation (Wenger, 1999). As Ntibagirirwa (2009) points out, from this position:

$[O]$ ne achieves one's humanity as a producer and a consumer, or a buyer and a seller, who responds not only to the forces of the market but also to both the material and spiritual needs of the being human. This is the very meaning of ubuntu; I mean the ubuntu economy. (p. 307)

This expresses the essence of African human consciousness, and the application of the inherent values of Ubuntu ecology of humanity into responsive business practice (Ntibagirirwa, 2009).

One way the shared African human values identified in the study could be used to enhance effective African leadership and business practice is by adopting what (Wenger, 1999) refers to as a community of practice approach. Adopting such a perspective within the African context is a way of honouring the heartbeat of African humanism, bringing values to the heart of business practice. To operationalise this value-oriented practice, businesses need to develop relevant human capital in a manner that translates the embedded values into core processes, protocols and goalsetting strategies of organisations (Vilakati et al., 2018).

\section{Practical implications}

The findings of the study as illustrated in Figure 1 have several implications for business leadership research and practice.

The study offers an outline (Figure 1) to better understand the shared African human values used in business practice, and their context and formational influences. The shared African human values identified by analysing the real-life experiences of the three African leaders offer building blocks that make leaders and researches aware of the extent and use of these values in taking decisions.

The findings reveal the unfulfilled need to develop business leaders who will more fully embrace the use of shared African values in the workplace. Such integration promises a more humane organisational culture as well as a sustainable balance in internal and external stakeholder relationships.

Finally, the research findings can be used by business strategists and leadership development practitioners to (1) enhance the active use of shared African human values in the workplace to improve leadership practice and (2) enhance the active use of shared African human values in improving business' financial and social performance as well as their sustainability.

\section{Limitations and recommendations for future research}

\section{Limitations}

The study's qualitative-constructivist approach in exploring the subjective experiences of three purposively selected African business leaders may be criticised, especially by those who adhere to positivist-oriented perspectives. They will most certainly regard the sample of three leaders as not representative of cultures and business leaders across the continent. Exponents of non-positivistic approaches whilst 
not concerned with a small number of cases may raise questions about whether the information obtained from the three leaders is sufficiently rich. Also, as is true with other autobiographical work, valuable insights might have been overlooked and/or additional themes might have been revealed by employing a different analytic technique.

\section{Recommendations for future research}

Further research is required to confirm the actual level African business leaders of various racial and ethnic origins are concerned, about with the ability to lead with African values. We need to better understand whether managers think of leading with African values, whether they are ignorant of this or whether they practice it or are opposed to it. Differently phrased, how transcendent are these values? This information is necessary to provide concrete information as to where to start to bring values to the African business setting. Finally, it would be of great benefit to compare these African values and insights with the experiences of other business leaders from other continents.

\section{Conclusion}

Even though Africa is home to 54 countries and hundreds of traditional cultures, African leadership and management scholarship have identified a host of shared human values. When effectively incorporated into strategies and practice of business leadership, these values could enhance these as well and their sustainability.

The three African leaders' life histories provide a tentative understanding of the context, influences and formation of these values in daily activities. Careful consideration of how to implement the role of shared African human values has the potential to change the role of business in society. Finally, there is a need to apply the same principles of the current study, analysing the same concepts to study African heads of state on the possibility of eliminating corruption and moving the continent forward.

\section{Acknowledgements}

The authors would like to acknowledge the contribution of Prof. René Celliers in the initial conceptualisation of this article. The authors would also like to acknowledge Prof. Scott Hoenig for his contribution during the research and data analysis process.

\section{Competing interests}

The authors declare that they have no financial or personal relationships that may have inappropriately influenced them in writing this article.

\section{Authors' contributions}

V.M.V. under the guidance of W.S. conceptualised, researched, analysed and compiled every draft of the research article.
W.S. contributed as a supervisor, mainly guiding with the structure, methodology and editing of the article. The final product was a collaborative exercise of revisions and sharpening of the arguments through an iterative engagement between V.M.V. and W.S.

\section{Funding information}

This research received no specific grant from any funding agency in the public, commercial or not-for-profit sectors.

\section{Data availability}

This article is a directive of a PhD thesis project submitted to the University of Johannesburg. The complete scope of the data is available through the university's thesis repository.

\section{Disclaimer}

The views and opinions expressed in this article are those of the authors and do not necessarily reflect the official policy or position of any affiliated agency of the authors.

\section{References}

Abegunrin, O., \& Abidde, S.O. (2016). Pan-Africanism in modern times: Challenges, concerns, and constraints. London: Lexington Books.

Adesida, O.J., Karuri-Sebina, G., \& Resende-Santos, J. (2016). Innovation Africa Emerging hubs of excellence. London: Emerald Group Publishing. Retrieved from http://0-search.ebscohost.com.ujlink.uj.ac.za/login.aspx?direct=true\&db=nlebk \&AN $=1423658 \&$ site $=$ ehost-live $\&$ scope $=$ site

Ahluwalia, P. (2012). Politics and post-colonial theory: African inflections. London: Routledge.

Amah, O.E. (2019). African leadership process in the development of globalisation. Retrieved from https://0-link-springer-com.ujlink.uj.ac.za/chapter/10.1007/9783-319-98764-4_5

Asamoah, K., \& Yeboah-Assiamah, E. (2019). 'Ubuntu philosophy' for public leadership and governance praxis: Revisiting the ethos of Africa's collectivism. Journal of Global Responsibility, 10(4), 307-321. https://doi.org/10.1108/JGR01-2019-0008

Ashom, N. (2018). Africa is my business. IOL. Retrieved from https://www.iol.co.za/ business-report/opinion/opinion-africa-is-my-business-15143402

Ayuso, S., Rodríguez, M.A., García-Castro, R., \& Ariño, M.A. (2014). Maximizing stakeholders' interests: An empirical analysis of the stakeholder approach to corporate governance. Business \& Society, 53(3), 414. https://doi.org/10.2139/ ssrn.982325

Bass, B.M., \& Bass, R. (2009). The Bass handbook of leadership: Theory, research, and managerial applications. London: Simon and Schuster.

Bell, R.H. (2002). Understanding African philosophy: A cross-cultural approach to classical and contemporary issues. London: Psychology Press.

Biko, H. (2019). Africa reimagined: Reclaiming a sense of abundance and prosperity. Cape Town: Jonathan Ball. Retrieved from http://0-search.ebscohost.com.ujlink. uj.ac.za/login.aspx?direct=true $\& d b=n l e b k \& A N=2105776 \&$ site=eds-live \&scope=site

Biko, S. (1987). I write what I like: A selection of his writings. Johannesburg: Heinemann. Brinkmann, S., \& Kvale, S. (2018). Doing interviews. Thousand Oaks, CA: Sage.

Butler-Kisber, L. (2010). Qualitative inquiry: Thematic, narrative and arts-informed perspectives. London: Sage.

Charmaz, K. (2016). Shifting the grounds: Constructivist grounded theory methods. In J.M. Morse, P.N. Stern, J. Corbin, B. Bowers, K. Charmaz, \& A.E. Clarke (Eds.) Developing grounded theory: The second generation (pp. 127-155). London: Routledge.

Coetzee, P.H., \& Roux, A.P.J. (2004). The African philosophy reader. London: Routledge. Cooper, B., \& Morrell, R. (Eds.). (2014). Africa-centred knowledges: Crossing fields and worlds (New edn.). Suffolk: Boydell \& Brewer.

De Chesnay, M. (2014). Nursing research using life history: Qualitative designs and methods in nursing. New York: Springer Publishing Company

Denzin, N.K., \& Lincoln, Y.S. (Eds.). (2017). The SAGE handbook of qualitative research (5th edn.). London: Sage.

Edozie, R.K. (2017). Charting new frames for African global engagement: Resuscitated histories, reimagined concepts, and reapplied contexts. In R.K. Edozie (Eds.), 'Pan' Africa rising (pp. 23-51). New York, NY: Palgrave Macmillan.

Ellis, C. (2004). The ethnographic I: A methodological novel about autoethnography. New York, NY: AltaMira Press. 
Encyclopedia.com. (2019). Humanism: Africa. New Dictionary of the history of ideas. Retrieved from https://www.encyclopedia.com/history/dictionaries-thesaurusesRetrieved from https://WwW.encyclopedia.com
pictures-and-press-releases/humanism-africa

Forster, D.A. (2010). A generous ontology: Identity as a process of intersubjective discovery - An African theological contribution. HTS Teologiese Studies/ Theological Studies, 66(1), 1-12. https://doi.org/10.4102/hts.v66i1.731

Fourie, W., Van Der Merwe, S.C., \& Van Der Merwe, B. (2017). Sixty years of research on leadership in Africa: A review of the literature. Leadership, 13(2), 222-251. https://doi.org/10.1177/1742715015580665

Goodson, I.F. (2016). The story of life history. In I.F. Goodson, A. Antikainen, P. Sikes, \& $\mathrm{M}$. Andrews (Eds.), The Routledge International handbook on narrative and life history (pp. 23-33). London: Routledge.

Gumede, V. (2017). Leadership for Africa's development: Revisiting indigenous African leadership and setting the agenda for political leadership. Journal of Black Studies, 48(1), 74-90. https://doi.org/10.1177/0021934716678392

Gutto, S.B.O. (2013). In search of real justice for Africa and Africans, and her/their descendants in a world of justice, injustices and impunity. International Journal of African Renaissance Studies - Multi-, Inter- and
https://doi.org/10.1080/18186874.2013.834553

Hassanzadeh, M., Silong, A.D., Asmuni, A., \& Wahiza, N. (2015). Global leadership competencies. Journal of Educational and Social Research, 5(2), 137-146. https:// doi.org/10.5901/jesr.2015.v5n2p137

Irele, A., \& Jeyifo, B. (2010). The Oxford encyclopedia of African thought. New York NY: Oxford University Press.

Iwowo, V. (2015). Leadership in Africa: Rethinking development. Personnel Review, 44(3), 408-429. https://doi.org/10.1108/PR-07-2013-0128

Jackson, T. (2004). Management and change in Africa: A cross-cultural perspective. Abingdon: Taylor \& Francis. Retrieved from http://www.tandfebooks.com/action/ Abingdon: Taylor \& Francis. Retrieved from
showBook?doi=10.4324/9780203477069

Jackson, T. (2015). Management studies from Africa: A cross-cultural critique. Africa Journal of Management, 1(1), 78-88. https://doi.org/10.1080/23322373.2015. 994425

Jackson, T. (2018). What makes cross-cultural management scholarship critical? It depends on how we understand 'culture'. International Journal of Cross Cultural Management, 18(3), 267-270. https://doi.org/10.1177/1470595818816414

Jacques, T.C.F. (2011). Philosophy in black: African philosophy as a negritude. Sartre Studies International, 17(1), 1-19. https://doi.org/10.3167/ssi.2011.170101

Kamoche, K., Chizema, A., Mellahi, K., \& Newenham-Kahindi, A. (2012). New directions in the management of human resources in Africa. The International Journal of Human Resource Management, 23(14), 2825-2834. https://doi.org/10.1080/095 85192.2012.671504

Kazeroony, H. (2016). Sustainable management development in Africa: Building capabilities to serve African organizations. New York: Routledge.

Khoza, R.J. (2007). Values dominate the African leadership paradigm. Management Today, 23(6), 24-27.

Lincoln, Y.S., \& Guba, E.G. (1985). Naturalistic inquiry. London: Sage.

Lutz, D.W. (2009). African ubuntu philosophy and global management. Journal of Business Ethics, 84(S3), 313-328. https://doi.org/10.1007/s10551-009-0204-z

Malunga, C. (2009). Understanding organizational leadership through Ubuntu. London: Adonis \& Abbey Publishers.

Maslin, M. (2017). The cradle of humanity: How the changing landscape of Africa made us so smart. Oxford: Oxford University Press.

Matupire, P.M. (2016). Integral ubuntu leadership. London: Taylor \& Francis Group.

Mbiti, J.S. (2015). Introduction to African religion (2nd edn.). Long Grove, IL: Waveland Press.

Menter, I., Elliot, D., Hulme, M., Lewin, J., \& Lowden, K. (2011). A guide to practitioner research in education. Thousand Oaks, CA: Sage.

Mngxitama, A., Alexander, A., \& Gibson, N.C. (Eds.). (2008). Biko lives! Contesting the legacies of Steve Biko (1st edn.). New York, NY: Palgrave Macmillan.
Msila, V. (Ed.). (2017). Decolonising knowledge for Africa's renewal: (Re)-examining African perspectives and philosophies. Randburg: KR Publishing.

Ndlovu, M. (2015). African leadership in the age of Euro-North American-centric modernity: A decolonial critique of Robert Mugabe. In S.J. Ndlovu-Gatsheni (Ed.), Mugabeism? History, Politics and Power in Zimbabwe (pp. 237-248). New York, NY: Palgrave Macmillan.

Nkomo, S.M. (2006). In search of African leadership. Management Today, 22(5), $10-11$.

Nkomo, S.M. (2015). Challenges for management and business education in a 'developmental' state: The case of South Africa. Academy of Management Learning \& Education, 14(2), 242-258. https://doi.org/10.5465/amle.2014.0323

Ntibagirirwa, S. (2009). Cultural values, economic growth and development. Journa of Business Ethics, 84(S3), 297-311. https://doi.org/10.1007/s10551-009-0203-0

Pillay, P., Subban, M., \& Govender, V. (2013). Perspectives on African leadership in the spirit of ubuntu. African Journal of Public Affairs, 6(2), 104-115.

Plummer, K. (2001). Documents of life 2: An invitation to a critical humanism. London: Sage Publications.

Rukuni, M. (2007). Being Afrikan. Johannesburg: Penguin Global.

Rukuni, M. (2009). Leading Afrika. Johannesburg: Penguin Global.

Schurink, W.J. (2009). The internal audit as tool to enhance the quality of qualitative research. Journal of Public Administration, 44(Special issue 2), 788-802.

Schurink, W.J. (2011). On writing qualitatively, email notes to master and doctoral students. Pretoria: Silver Lakes.

Schwab, K., \& Davis, N. (2018). Shaping the future of the fourth industrial revolution: A guide to building a better world. Westminster: Penguin.

Schwandt, T.A. (2014). The SAGE dictionary of qualitative inquiry. Los Angeles, CA Sage.

Taylor, S.J., \& Bogdan, R. (1984). Introduction to qualitative research methods: The search for meanings. Hoboken, NJ: Wiley \& Sons.

Tutu, D., (1999). God has a dream: A vision of hope for our time. New York, NY: Doubleday.

Veldsman, T., \& Johnson, A. (Eds.). (2016). Leadership: Perspectives from the front line. Randburg: KR Publishing.

Vilakati, V.M., Schurink, W.J., \& Van Wyk, R. (2018). Translating African human consciousness into evolving forms of leadership and organizational practice. In S.M. Lee, D. Kim, \& Y.-M. Yu (Eds.), Innovation for value creation and beyond (pp. 286-289). Seoul: Pan Pacific Business Association.

Viriri, A., \& Mungwini, P. (2010). African cosmology and the duality of western hegemony: The search for an African identity. Journal of Pan African Studies, 3(6), $27-42$.

Waddington, D. (2004). Participant observation. In C. Cassell \& G. Symonhe (Eds.), Essential guide to qualitative methods in organizational research (pp. 154-164) London: Sage.

Walsh, J.P. (2015). Organization and management scholarship in and for Africa ... And the world. Academy of Management Perspectives, 29(1), 1-6. https://doi. org/10.5465/amp.2015.0019

Ward, D.A. (2014). Teaching with the end in mind: A teacher's life history as a legacy of educational leaders. University of South Florida. Retrieved from http:// scholarcommons.usf.edu/etd/5401/

Wenger, E. (1999). Communities of practice: Learning, meaning, and identity. Cambridge: Cambridge University Press.

Wilder, G. (2005). The French imperial nation-state: Negritude and colonial humanism between the two world wars. Chicago, IL: University of Chicago Press.

Yin, R.K. (2013). Case study research: Design and methods. London: Sage.

Van Maanen, J. (1988). Tales of the field: On writing ethnography. Chicago, IL: University of Chicago Press. 